\title{
Effects of Antimalarial Drugs on Neuroinflammation-Potential Use for Treatment of COVID-19-Related Neurologic Complications
}

\author{
Wei-Yi Ong ${ }^{1,2}$ (1) $\cdot$ Mei-Lin Go ${ }^{3} \cdot$ De-Yun Wang ${ }^{4} \cdot$ Irwin Kee-Mun Cheah ${ }^{2,5} \cdot$ Barry Halliwell $^{2,5}$
}

Received: 31 May 2020 / Accepted: 25 August 2020 / Published online: 8 September 2020

(C) The Author(s) 2020

\begin{abstract}
The SARS-CoV-2 virus that is the cause of coronavirus disease 2019 (COVID-19) affects not only peripheral organs such as the lungs and blood vessels, but also the central nervous system (CNS) - as seen by effects on smell, taste, seizures, stroke, neuropathological findings and possibly, loss of control of respiration resulting in silent hypoxemia. COVID-19 induces an inflammatory response and, in severe cases, a cytokine storm that can damage the CNS. Antimalarials have unique properties that distinguish them from other anti-inflammatory drugs. (A) They are very lipophilic, which enhances their ability to cross the blood-brain barrier (BBB). Hence, they have the potential to act not only in the periphery but also in the CNS, and could be a useful addition to our limited armamentarium against the SARS-CoV-2 virus. (B) They are non-selective inhibitors of phospholipase $A_{2}$ isoforms, including cytosolic phospholipase $\mathrm{A}_{2}\left(\mathrm{cPLA}_{2}\right)$. The latter is not only activated by cytokines but itself generates arachidonic acid, which is metabolized by cyclooxygenase (COX) to pro-inflammatory eicosanoids. Free radicals are produced in this process, which can lead to oxidative damage to the CNS. There are at least 4 ways that antimalarials could be useful in combating COVID19. (1) They inhibit $\mathrm{PLA}_{2}$. (2) They are basic molecules capable of affecting the $\mathrm{pH}$ of lysosomes and inhibiting the activity of lysosomal enzymes. (3) They may affect the expression and $\mathrm{Fe}^{2+} / \mathrm{H}^{+}$symporter activity of iron transporters such as divalent metal transporter 1 (DMT1), hence reducing iron accumulation in tissues and iron-catalysed free radical formation. (4) They could affect viral replication. The latter may be related to their effect on inhibition of PLA 2 isoforms. Inhibition of $\mathrm{CPLA}_{2}$ impairs an early step of coronavirus replication in cell culture. In addition, a secretory $\mathrm{PLA}_{2}\left(\mathrm{sPLA}_{2}\right)$ isoform, PLA2G2D, has been shown to be essential for the lethality of SARS-CoV in mice. It is important to take note of what ongoing clinical trials on chloroquine and hydroxychloroquine can eventually tell us about the use of antimalarials and other anti-inflammatory agents, not only for the treatment of COVID-19, but also for neurovascular disorders such as stroke and vascular dementia.
\end{abstract}

Keywords SARS-CoV-2 · COVID-19 - COVID - SARS · Coronavirus · Antimalarials · Statins · Chloroquine · Hydroxychloroquine - Quinacrine - Aminoacridine - Cytosolic phospholipase $\mathrm{A}_{2} \cdot \mathrm{cPLA}_{2} \cdot$ Secretory phospholipase $\mathrm{A}_{2}$. sPLA $_{2}$ IID - TNF- $\alpha$. DMT1 - Iron transport - Arachidonic acid · Eicosanoids · Inflammation - Neuroinflammation · Microglia $\cdot$ Lysosomes $\cdot$ Oxidative stress $\cdot$ Free radical damage $\cdot$ Carotid body $\cdot$ Aortic body $\cdot$ Nucleus of the tractus solitarius . Glossopharyngeal nerve $\cdot$ Vagus nerve $\cdot$ Respiratory centre $\cdot$ Hippocampus $\cdot$ Stroke $\cdot$ Microvessels $\cdot$ Microcirculation $\cdot$ Brain endothelial cells · Vascular dementia

Wei-Yi Ong

antongwy@nus.edu.sg

Barry Halliwell

bchbh@nus.edu.sg

1 Department of Anatomy, Yong Loo Lin School of Medicine, National University of Singapore, Singapore 119260, Singapore

2 Neurobiology Programme, Life Sciences Institute, National University of Singapore, Singapore 119260, Singapore
3 Department of Pharmacy, Faculty of Science, National University of Singapore, Singapore 119260, Singapore

4 Department of Otolaryngology, Yong Loo Lin School of Medicine, National University of Singapore, Singapore 119260, Singapore

5 Department of Biochemistry, Yong Loo Lin School of Medicine, National University of Singapore, Singapore 119260, Singapore 


\section{COVID-19 Outbreak and the Use of Chloroquine and Hydroxychloroquine Against COVID-19}

The first cases of coronavirus disease 2019 (COVID-19) were reported near the end of 2019 in Wuhan, China. In March 2020, BBC and CNN news reported President Donald Trump's 'fantastic' treatment for coronavirus, chloroquine and hydroxychloroquine. As a result, hydroxychloroquine was snapped up by medical institutions at more than twice the typical pace, as US hospitals sought to build large inventories in anticipation of the medication's potential use in patients with COVID-19 (https://www. bloomberg.com/news/articles/2020-03-20/hospitalsstockpile-malaria-drug-trump-says-could-treat-covid-19). Nevertheless, the US Food and Drug Administration cautions against the use of chloroquine and hydroxychloroquine for COVID-19 outside of a hospital setting or a clinical trial due to risk of heart rhythm problems. While there are some reports suggesting that hydroxychloroquine could be a promising treatment intervention there have been, as yet, no large-scale randomized controlled trials to support those claims. Chloroquine and hydroxychloroquine have been used for the treatment of malaria, lupus and rheumatoid arthritis for many years. From the literature, serious side-effects seem quite rare when they are used to treat these diseases, apart from hemolysis in some patients with glucose-6-phosphate dehydrogenase deficiency and possible ocular side effects [1]. In this paper, we point out why they and other antimalarials might be effective in combatting certain aspects of COVID-19 infection, and the clinician has to balance this with the risk of side effects.

\section{COVID-19 Is a Proinflammatory Condition}

The SARS-CoV-2 virus, which is the cause of COVID-19, is known to infect both the upper airways and the lungs. The virus replicates in the lungs and can spread to other parts of the body through the vascular and possibly lymphatic systems (Fig. 1). COVID-19 causes an imbalance between adaptive and innate immunity. On one hand, there is decreased function of immune cells such as lymphocytes and $\mathrm{T}$ cell exhaustion, [2] but on the other, there is increased response from macrophages that are a key part of the innate immune response [3]. In some cases, a dysfunctional and hyperactive immune response can trigger a cytokine storm that mediates widespread lung inflammation. It has been observed that patients with severe COVID-19 that require intensive care in hospitals have greater macrophage inflammatory protein 1 in the plasma [4] and monocytederived FCN1+ macrophage population in the bronchoalveolar fluid [5]. Not only can the virus spread through the bloodstream, it can also infect endothelial cells in the vessel walls [6]. This could lead to an inflammatory response in these cells and an increase in blood coagulation. Hence, COVID-19 may predispose patients to thrombotic disease in the venous and arterial circulations due to excessive inflammation, platelet activation, endothelial dysfunction and stasis [7].

The problems of COVID-19 are aggravated by pre-existing medical conditions, in particular metabolic and cardiovascular diseases [8]. A common feature of these diseases is high levels of cholesterol oxidation products or oxysterols in the bloodstream [9]. In particular, 7-ketocholesterol has marked ability to induce cytokine expression and inflammation in cells. It induces the expression of the cytokines VEGF, IL- 6 and IL8 through the AKT-PKC $\zeta-N F \kappa B$, p38 MAPK and ERK pathways in ARPE-19 cells [10] and increases IL- $1 \beta$, TNF- $\alpha$, IL6 and IL-1 $\beta$ secretion and inflammation in these cells [11]. The oxysterol also markedly increases the formation and activation of NLRP 3 inflammasomes and elevates IL-1 $\beta$ levels in mouse carotid arterial endothelial cells [12]. This could aggravate damage to endothelial cells that are exposed to SARS-CoV-2. Serum 7-ketocholesterol level is associated with increased risk of cardiovascular events and mortality in patients with stable coronary artery disease [13]. Likewise, elevated plasma 7-ketocholesterol level is associated with the incidence of cardiovascular disease in a population-based cohort [14]. Increased 7-ketocholesterol levels are found in patients with diabetes or hypercholesterolemia [15].

Another factor that could be related to neuroinflammation is dysregulation of iron homeostasis [16]. Many patients with COVID-19 have increased iron, as reflected by an increased level of the iron storage protein, ferritin [17]. Excess iron is stored in cells by being bound to ferritin, but the latter can be downregulated by high levels of oxidative stress, resulting in release of iron ions that are capable of catalysing free radical reactions [18]. Iron transport across enterocytes in the intestines and across the blood-brain barrier (BBB) is dependent on the iron transporter, DMT1 [19]. The gene encoding the latter contains putative AP-1 and NF-kB binding sites, a possible interferon $\gamma$-responsive element and a hypoxia-inducible factor-1 (HIF-1)-like motif [20, 21]. It is therefore possible that increased AP-1 or NF- $\mathrm{KB}$ activation during a COVID-19-induced cytokine storm could result in activation of these sites on the DMT1 promoter, resulting in increased expression of the iron transporter and iron accumulation in tissues.

The ability of COVID-19 to produce a cytokine storm and inflammation might be at the centre of the pathogenicity of the virus, yet little is known about the component(s) of SARSCoV-2 that is pro-inflammatory. In the case of HIV, it is the gp120 protein that has been found to be pro-inflammatory in neurons [22]. Research is urgently needed to identify the proinflammatory component(s) of SARS-CoV-2. 


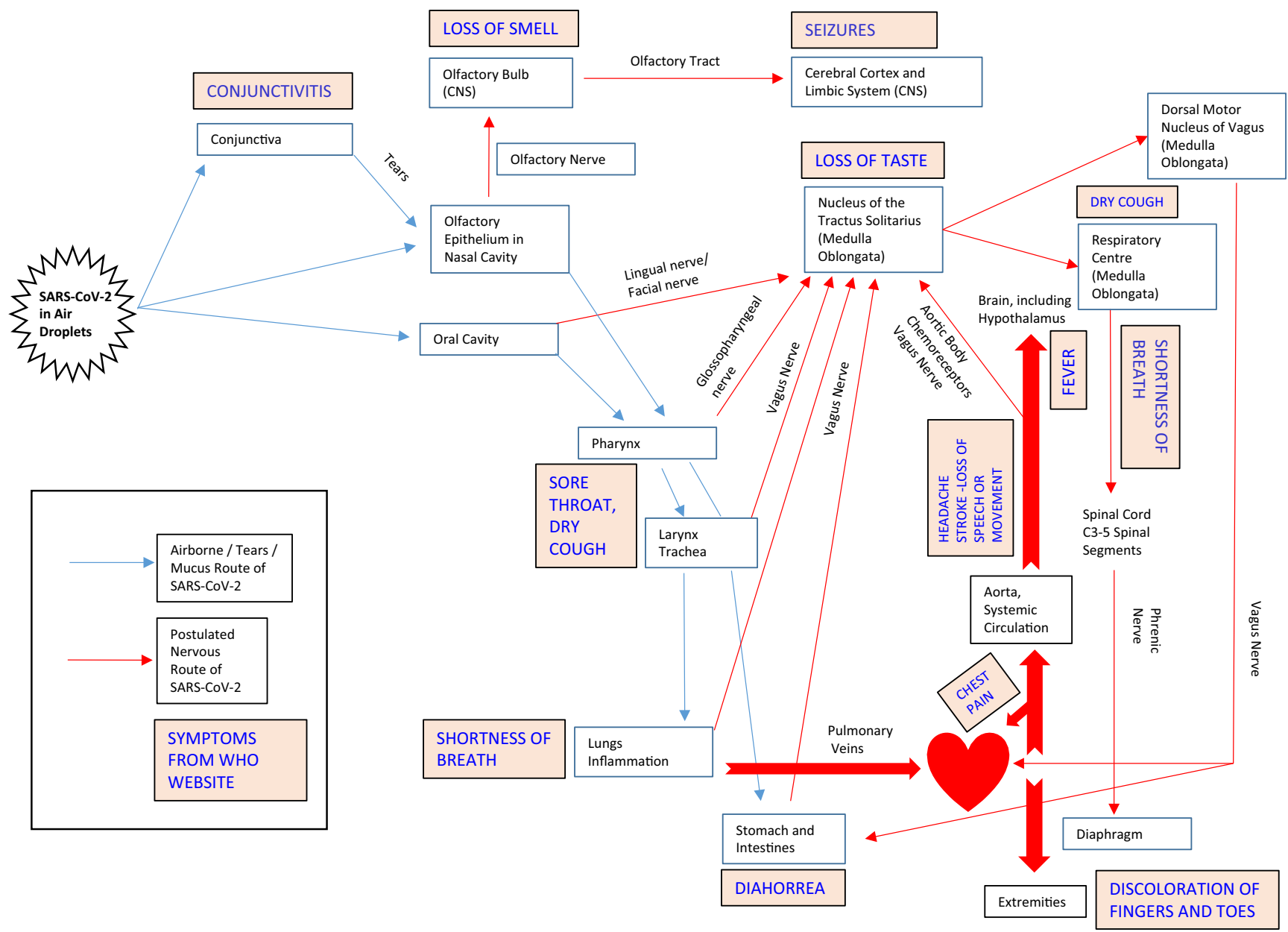

Fig. 1 Airborne/tears/mucus route of spread of SARS-CoV-2, postulated nervous route of the virus and COVID-19 symptoms

\section{COVID-19 Affects the CNS}

Besides peripheral effects, COVID-19 has also been reported to cause neurologic dysfunction (Fig. 1). Anosmia, stroke, paralysis, cranial nerve deficits, encephalopathy, delirium meningitis and seizures are some of the complications in patients with COVID-19 [23-25]. Many patients who have contracted COVID-19 report a loss in smell or taste [26]. The sense of smell originates from olfactory neurons in the olfactory epithelium in the upper part of the nasal cavity. It travels via bundles of the olfactory nerves to the olfactory bulb and thereafter along the olfactory tract to the septum, cerebral cortex and other parts of the brain. Damage to either the olfactory neurons or their supporting cells and/or the olfactory bulb could lead to anosmia [27]. Recent MRI studies have shown transient changes in the olfactory bulb that accompany COVID-19-related anosmia, consistent with CNS involvement in some of the patients $[28,29]$. Study of the intracerebral distribution of gold nanoparticles after inhalation exposure in rats shows that the nanoparticles are found in nuclei connected to the olfactory and limbic systems, including the olfactory bulb, hippocampus, frontal cortex, striatum, entorhinal cortex and septum [30,31]. This could be an indication of the potential areas of spread of viruses from the olfactory bulb. The SARS-CoV virus, which is taxonomically very similar to SARS-CoV-2, is able to enter the brain via the olfactory bulb, and infection results in rapid, transneuronal spread to connected areas of the brain. CNS infection is thought to be the main cause of death in mice experimentally infected with the SARS-CoV virus since intracranial inoculation with low doses of this virus results in lethality, even though little infection is detected in the lungs [32]. Besides the olfactory axonal route, SARS-CoV-2 may pass from nonneuronal olfactory epithelium cells directly to the cerebrospinal fluid surrounding olfactory nerve bundles and enter the brain [33]. Other viruses, e.g. herpesvirus-6 [34] or rabies virus, are also known to hijack existing vesicular axonal transport machineries to travel within the brain (reviewed in [35]).

Taste is also often affected by COVID-19. This modality is conveyed via axons in the facial, glossopharyngeal and vagus nerves that terminate in the nucleus of the tractus solitarius in the medulla oblongata. The loss of taste strongly suggests damage to this nucleus, possibly via retrograde transport of the virus along axons. It is interesting to note that the caudal 
part of the nucleus of the tractus solitarius receives visceral afferent signals from the airway that mediate the cough reflex, and it is possible that irritation of this nucleus could contribute to coughing, which is a common symptom of patients with COVID-19. Chemoreceptors in the carotid body or aortic body in the walls of the internal carotid artery or the aorta sense the level of oxygen or carbon dioxide in the blood and convey these signals via the glossopharyngeal and vagus nerves to the nucleus of the tractus solitarius. Moreover, afferent fibres in the vagus nerve convey the sense of stretch from the lungs to the same nucleus, and these are involved in the reflex control of respiratory rate. It is possible that interference with chemoreceptors as a result of vasculitis or inflammatory changes in the vessel walls $[6,36]$ and/or the nucleus of the tractus solitarius [37] could lead to loss of feedback control to regulate the oxygenation in the blood and might explain the 'silent hypoxia' or 'happy hypoxia' even without lung exudates in many patients with COVID-19 [33, 38]. Localized perivascular and interstitial encephalitis with neuronal cell loss and axon degeneration in the dorsal motor nucleus of the vagus nerve, trigeminal nucleus and nucleus tractus solitarii have been detected in the brains of patients with COVID-19 [37]. COVID-19 may also be associated with unexplained altered mental status or loss of consciousness in $13 \%$ of patients [39]. Study of 26 critically ill hospitalized SARS-CoV-2 patients with unexplained neurological symptoms found that 5 patients had EEGs with biphasic delta periodic discharges indicative of CNS injury [40].

Previous studies have shown the ability of SARS-CoV to induce neuronal death in mice by invading the brain via the olfactory epithelium [32]. Entry of coronavirus into the primate CNS has also been demonstrated after peripheral infection [41]. SARS-CoV is present in brain tissue from human autopsies, and tissue oedema and neuronal degeneration were prominent findings in sections [42]. Moreover, the SARS genomic sequence has been detected by in situ hybridization histochemistry in brain neurons of a patient infected by SARS-CoV [42]. In the current pandemic, gene sequencing confirmed the presence of SARS-CoV-2 in the cerebrospinal fluid of a 56-year-old patient with novel coronavirus in Beijing Ditan Hospital [43]. COVID-19 effects on the brain may be an extension of its effects on the periphery. The same cytokines that cause inflammation in the periphery, most commonly, IL- $1 \beta$, TNF- $\alpha$ and IL-6, may also induce neuroinflammation in the brain [44]. Brain inflammation has been shown to underlie, at least in part, the CNS damage associated with infection by West Nile, Zika and herpes simplex viruses, conditions in which long-lasting inflammatory processes develop within the CNS [35]. Intracranial cytokine storm has been implicated in causing COVID-19-related acute necrotizing haemorrhagic encephalopathy. This can lead to symmetric thalamic encephalitis as well as similar symmetric lesions in other brain regions [45]. Cerebral microbleeds and leukoencephalopathy have also been detected in critically ill patients with COVID-19 [46]. It is likely that the paucity of brain imaging studies being performed in critically ill COVID-19 patients may be an important factor in the lack of wider recognition of such complications.

Besides a possible route to the brain via peripheral nerves, the SARS-CoV-2 virus might gain entry into the brain by infecting endothelial cells [6]. Observations of viral-like particles in brain capillary endothelium and active budding across endothelial cells suggest a role of brain microvessels as a route of SARS-CoV-2 entry into the brain [47]. Damage to cerebral blood vessels may also predispose the patients to stroke [48] and possibly vascular dementia. The intense systemic inflammatory response linked to viral infections may lead to damage to the blood-brain barrier (BBB), thus allowing more virus or peripheral cytokines including TNF- $\alpha$ (which is neurotoxic [49]) to enter the brain where they may trigger or exacerbate neuroinflammation. Since the hippocampus is well known to be particularly susceptible to global ischemia, this structure could also be damaged by prolonged silent hypoxemia in patients with severe COVID-19, with resultant effects on declarative memory.

Like the SARS-CoV virus, SARS-CoV-2 uses a spike protein $\mathrm{S} 1$ to enable the virus to gain entry to cells by attaching to the host ACE2 receptor [50] and TMPRSS2 priming on the cell membrane. ACE2 receptor is highly expressed in the lungs, heart, liver and CNS, which includes the olfactory bulb while TMPRSS2 is expressed in the liver, peripheral nervous system and CNS [51].

\section{Phospholipase $A_{2}\left(P L A_{2}\right)$ Plays a Critical Role in Coronavirus Replication and Pathogenicity}

The enzyme cytosolic phospholipase $\mathrm{A}_{2}\left(\mathrm{cPLA}_{2}\right)$ is a key enzyme in innate immunity. It acts on membrane glycerophospholipids to release a free fatty acid (arachidonic acid) and a lysophospholipid. Arachidonic acid can be further metabolized by cyclooxygenases (COX) to prostaglandins and other pro-inflammatory mediators. Hence, inhibition of cPLA $_{2}$ has been found by many groups to have an antiinflammatory and neuroprotective effect (for reviews, see $[52,53])$. Increased cPLA $\mathrm{A}_{2}$ activity is found in microglial cells that are stimulated by lipopolysaccharide (LPS) or interferon gamma (IFN $\gamma)$. On the other hand, LPS- and IFN $\gamma$-induced production of reactive oxygen species (ROS) and nitric oxide (NO) are inhibited by a selective inhibitor of $\mathrm{cPLA}_{2}$, arachidonyl trifluoromethyl ketone $\left(\mathrm{AACOCF}_{3}\right)$ [54]. ROS such as superoxide radicals, hydrogen peroxide and hydroxyl radicals and reactive nitrogen species such as nitric oxide or peroxynitrite can cause damage to cellular components if present in excess [18]. cPLA $A_{2}$ could be a link between the increased cytokine production that is found in COVID-19 and 
inflammation and oxidative stress. MAPKs and NF- $\mathrm{BB}$ have been shown to be involved in IL- $1 \beta$-induced $\mathrm{cPLA}_{2}$ expression in canine tracheal smooth muscle cells [55], and TNF $\alpha$ has been shown to induce PLA $_{2}$ expression in lung epithelial cells [56]. A pathway for cPLA 2 activation via IL-13 has also been described [57]. Since cPLA 2 expression is increased by cytokines and itself forms eicosanoids that are pro-inflammatory, it could be a key enzyme in a feed-forward cycle to propagate a cytokine storm.

As a cellular defence against such oxidative damage, arachidonic acid that is formed by $\mathrm{cPLA}_{2}$ is bound by the lipocalin apolipoprotein $\mathrm{D}$ (apoD) and prevented from forming toxic lipid peroxides [58]. It is interesting to note that overexpression of human apoD in neurons of Thy-1/apoD transgenic mice resulted in a threefold increase in the number of mice surviving coronavirus (HCoV-OC43) infection [59]. $\mathrm{cPLA}_{2}$ is also found to be essential for coronavirus replication. Inhibition of this enzyme is reported to impair an early step of coronavirus replication in cell culture, probably due to interference with the formation of lysophospholipids [60].

A critical role of another member of the $\mathrm{PLA}_{2}$ superfamily, secretory phospholipase $\mathrm{A}_{2}\left(\mathrm{sPLA}_{2}\right)$ Group IID in age-related susceptibility to SARS-CoV infection, has also been reported. Strikingly, infection of mice lacking PLA2G2D (Pla2g2d ( $/$ ) mice) converted a uniformly lethal infection to a nonlethal one ( $>80 \%$ survival), together with enhanced antivirus $\mathrm{T}$ cell responses and diminished lung damage [61].

\section{Effects of Antimalarials on Phospholipase $A_{2}$}

How might antimalarials help in COVID-19? There are at least four possibilities: (1) They inhibit $\mathrm{PLA}_{2}$; (2) they are basic molecules capable of affecting the $\mathrm{pH}$ of lysosomes and inhibiting the activity of lysosomal enzymes; (3) they may affect the expression and $\mathrm{Fe}^{2+} / \mathrm{H}^{+}$symporter activity of iron transporters such as divalent metal transporter 1 (DMT1), hence reducing iron accumulation in tissues and ironcatalysed free radical formation [62]; and (4) they may affect viral replication (Figs. 2, 3 and 4). Chloroquine, hydroxychloroquine and quinacrine are known to be non- selective inhibitors of different $\mathrm{PLA}_{2}$ isoforms. They enter and accumulate in lysosomes and are thought to act by altering the $\mathrm{pH}$ of lysosomes. This results in inhibition of lysosomal enzymes in the malarial parasite and interference with parasite feeding [63]. Among the lysosomal enzymes are a wide range of proteases, lipases and nucleases. An inhibitory effect on malarial $\mathrm{PLA}_{2}$ has been shown with chloroquine, quinine and arteether (derived from artemisinin) [64]. Moreover, chloroquine and mepacrine (quinacrine) inhibit $\mathrm{CPLA}_{2}$ in rat heart homogenates [65]. Antimalarial drugs inhibit $\mathrm{PLA}_{2}$ activation and induction of IL- $1 \beta$ and TNF $\alpha$ in macrophages. Chloroquine, quinacrine and, to a lesser extent, hydroxychloroquine inhibit arachidonic acid release and eicosanoid formation induced by phorbol diester in macrophages. This effect is due to inhibition of arachidonic-acid preferring $\mathrm{PLA}_{2}\left(\mathrm{cPLA}_{2}\right)$ [66]. Besides inhibition of PLA activity, Northern blot analyses showed that quinacrine reduced $\mathrm{cPLA}_{2}$ mRNA expression in the rat hippocampus after kainate-induced excitotoxic injury [67]. It also reduced cPLA immunoreactivity and protected neurons from cellular injury in hippocampal slice cultures after kainate treatment [68]. Moreover, quinacrine reduced $\mathrm{cPLA}_{2}$ immunoreactivity in glial cells and protected neurons from damage after intracerebroventricular lipopolysaccharide injection [69]. Quinacrine has been found to block the binding of the transcription factor AP-1 to its binding site on DNA and could reduce AP-1-induced gene expression in target cells [70], i.e. it both inhibits and deceases the expression of $\mathrm{cPLA}_{2}$. All isoforms of bovine brain $\mathrm{PLA}_{2}$ are strongly inhibited by antimalarial drugs in a dose-dependent manner. Chloroquine, quinacrine, hydroxychloroquine and quinine inhibit bovine brain $\mathrm{cPLA}_{2}$ with $\mathrm{IC}_{50}$ values of $125,200,185$ and $250 \mu \mathrm{M}$ $[53,71]$. Chloroquine or quinacrine have been found to reduce cPLA $_{2}$ immunoreactivity in hippocampal slice cultures following kainate treatment. Interestingly, the effects on $\mathrm{cPLA}_{2}$ expression are observed at $10 \mu \mathrm{M}$ chloroquine or quinacrine, i.e. concentrations that are about an order of magnitude lower than the $\mathrm{IC}_{50}$ of these inhibitors for $\mathrm{CPLA}_{2}$. These drugs may therefore not only inhibit $\mathrm{CPLA}_{2}$ enzymatic activity at higher concentration but also induce downregulation of $\mathrm{CPLA}_{2}$ protein expression at lower concentrations [71]. Other isoforms of
Fig. 2 Potential effects of antimalarials on COVID-19

\section{Postulated Effects of Antimalarials on COVID-19}

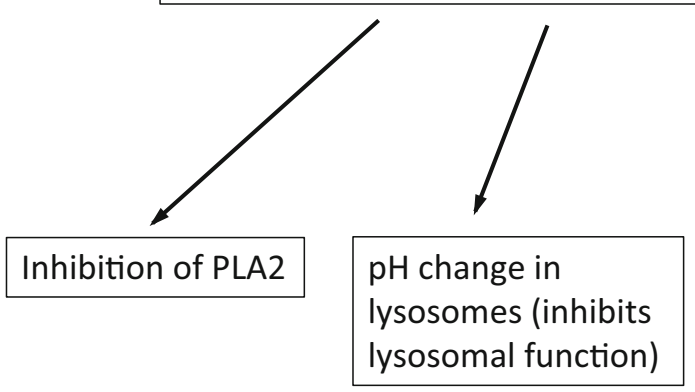

Inhibition of viral replication 
Fig. 3 Structure of chloroquine, hydroxychloroquine, quinacrine and quinacrine derivatives. a Monoprotonated chloroquine and diprotonated chloroquine. $\mathbf{b}$

Red-hydrophobic domains in molecules; blue - basic centres in molecules

a

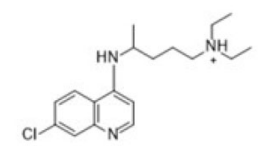

Monoprotonated chloroquine - membrane permeable

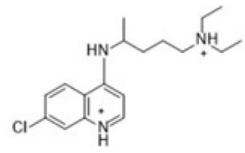

Diprotonated chloroquine - membrane impermeable b

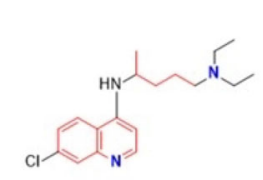

Chloroquine

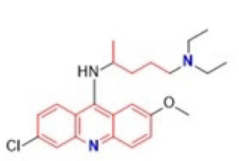

Quinacrine

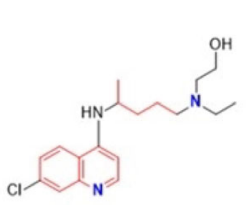

Hydroxychloroquine
Monoprotonated chloroquine and diprotonated chloroquine
Chloroquine and hydroxychloroquine

against malaria, COVID-19

Red: hydrophobic domains in molecule Blue : basic centres in molecule.
$\mathrm{PLA}_{2}$, such as sPLA 2 , are also important in inflammation, but even then, their ability to induce arachidonic acid release is dependent on $\mathrm{cPLA}_{2}$ [72]. Gene knockout of $\mathrm{cPLA}_{2}$ results in downregulation of its downstream enzyme cyclooxygenase- 2 (COX-2) leading to a reduction in eicosanoid production including the pro-inflammatory PGE2. sPLA $_{2}$ and calciumindependent phospholipase A2 (iPLA2) do not compensate for the loss of brain cPLA2 [73].

The CNS penetration ability of drugs has been reported to be a critical factor in the treatment of SARS-CoV-2 brain infection [74]. Among antimalarials, there is compelling evidence to support the BBB permeability of mefloquine, a quinolinemethanol that is structurally related to quinine $[75$, 76]. Less is known of the potential of chloroquine and hydroxychloroquine to transverse the BBB. Studies have shown that certain structural properties may be used to predict the BBB permeability of solutes [77]. One such set of empirical rules was articulated by Clark [78] and Lobell et al. [79] who stated that access into the central nervous system required molecules to fulfil the following threshold values: (i) molecular weight $<450$; (ii) polar surface area (PSA) $<60-70 \AA^{2}$; (iii) total number of $\mathrm{N}$ and $\mathrm{O}$ atoms $<6$; (iv) distribution coefficient Log D 7.4 between 1 and 3; (v) $\operatorname{clog} \mathrm{P}-(\mathrm{N}+0)>0$. Functional groups with $\mathrm{N}$ and $\mathrm{O}$ atoms and the $\mathrm{H}$ atoms attached to them contribute to the polar surface area of the molecule, and together, both parameters are surrogate measures of the hydrogen bonding capacity of the molecule. Lipophilicity is assessed from clogP, which is derived from the neutral

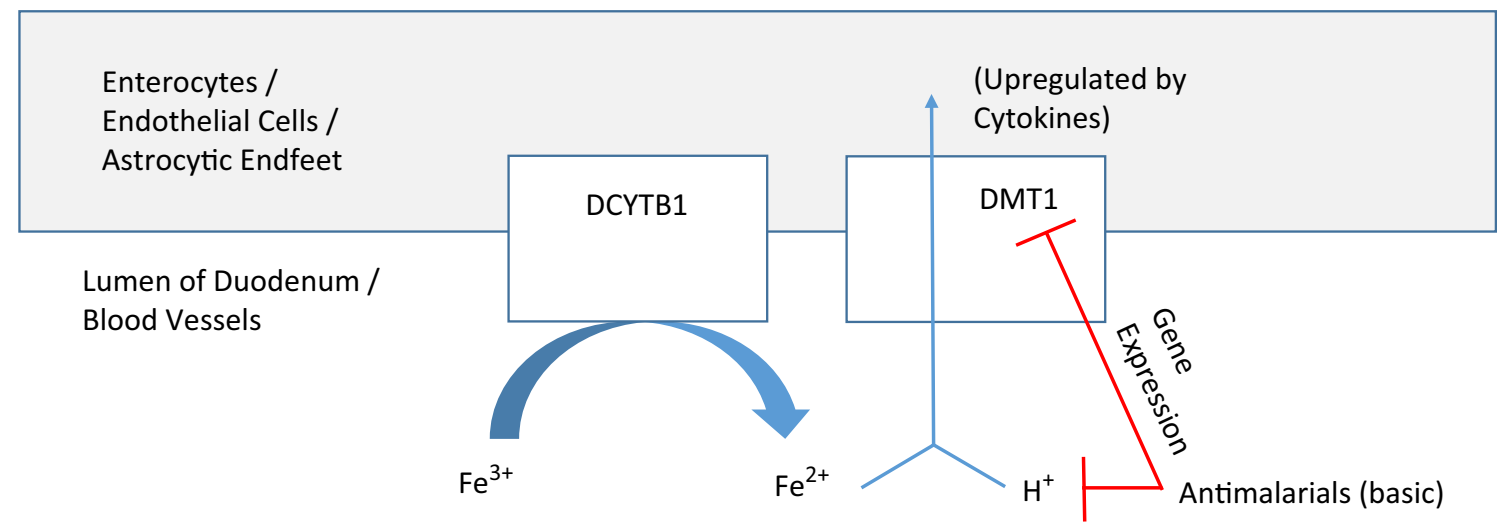

Fig. 4 Effect of quinacrine on iron transport through DMT1 in the duodenum and blood-brain interface. Ferric iron is converted to ferrous iron by duodenal cytochrome B (DCTB). Thereafter ferrous iron is taken up into enterocytes, endothelial cells or astrocytes by divalent metal

transporter-1 (DMT1) together with a proton $\left(\mathrm{H}^{+}\right)$. Antimalarials reduce the number of protons available for the $\mathrm{H}^{+} / \mathrm{Fe}^{2+}$ symporter activity of DMT1. Quinacrine also reduces DMT1 expression itself 
(non-ionized) state of the molecule, and $\log \mathrm{D}$, which measures the contribution of both non-ionized and ionized states of the molecule at a stated $\mathrm{pH}$, usually $\mathrm{pH}$ 7.4. Here, we obtained the parameters $(i-v)$ of chloroquine and hydroxychloroquine and compared them with those of mefloquine (Table 1). The parameters of quinacrine were also included as this compound was found to possess a PAMPA Pe value that was indicative of BBB permeability [80]. As seen from Table 1, both chloroquine and hydroxychloroquine fulfilled the requirements stated for molecular weight, polar surface area and hydrogen bonding propensity (PSA, number of $\mathrm{N}, \mathrm{O}$ atoms; $\operatorname{clog} \mathrm{P}-[\mathrm{N}+\mathrm{O}])$ required for $\mathrm{CNS}$ penetration. The size, lipophilicity and $\mathrm{H}$ bonding capability of hydroxychloroquine are, in fact, closely aligned to that of mefloquine, and the parameters obtained for quinacrine lend support to its 'CNS +' status as implicated from its PAMPA Pe.

The ability of antimalarials to cross the BBB could be particularly important, in view of the neuroinvasive potential of SARS-CoV and SARS-CoV-2 and the observations noted above that many COVID-19 patients have loss of control of respiration and silent hypoxemia even without lung exudates $[38,81]$. Rats that received a fimbria-fornix lesion showed increased $\mathrm{cPLA}_{2}$ in the septum (cell body of some of the transected axons), accompanied by an increase in the oxidative stress marker, 4-hydroxynonenal (4-HNE) [18]. The latter is a breakdown product of peroxidized arachidonic acid that has been released from membrane glycerophospholipids by the action of $\mathrm{CPLA}_{2}$. It contains reactive alkene and aldehyde groups and can form adducts with and inhibit the function of cellular proteins. Intraperitoneal injection of quinacrine to rats results in significant reduction of both $\mathrm{CPLA}_{2}$ - and HNE-positive cells in the septum [82]. Observation of the brains of rats that have received prior intraperitoneal quinacrine injections showed that the brains were stained yellow due to the antimalarial drug, demonstrating clearly that it can cross the BBB. This confirms the findings of an early study in primates that quinacrine is able to enter almost all tissues in the body from the bloodstream and remain detectable for at least a week even after blood levels have subsided [83]. The ability of quinacrine and other antimalarials to function as cPLA $_{2}$ inhibitors that are able to cross the BBB could enable them to act centrally within the brain, in addition to their peripheral effect, and could be a unique action among existing anti-inflammatory agents, which is perhaps shared with some of the brain-permeable statins [84-86].

\section{Effect of Antimalarials on pH and Lysosomal Enzymes}

Chloroquine and hydroxychloroquine are lipophilic molecules as seen from their estimated clogP values (Table 1; Fig. 3). They are also strong bases with two ionizable basic groups - a weakly basic quinoline ring $\mathrm{N}$ (pKa 6.3) and a strongly basic side chain tertiary amine (pKa 10.5, 8.9) (Table 1). Chloroquine is a known lysosomotropic agent. It accumulates within lysosomes, which are highly acidic organelles. Accumulation within lysosomes is driven by the physicochemical character of these molecules. The monoprotonated state, which is the main species at physiological $\mathrm{pH}$, diffuses across the lysosomal membranes and, once within the highly acidic environment of the lysosomes, acquires protons to become the less permeable diprotonated form. The latter is consequently trapped within the lysosomes, thus inducing an increase in the $\mathrm{pH}$ of the compartment due to the acquisition of protons to form the diprotonated state. Hence, enzyme activity or any metabolic process within the lysosomes that requires a low $\mathrm{pH}$ is impaired. For the malarial parasite, this translates to an interference with parasite feeding. This is one way by which chloroquine and related compounds exert their antimalarial properties. We have earlier synthesized and reported two acridine derivatives that have greater activity than quinacrine against prions [87]. These compounds retain the motif that is associated with lysosomotropic activity (lipophilic and with two basic centres). The structures of chloroquine, hydroxychloroquine, quinacrine and derivatives of quinacrine are shown in Fig. 3.
Table 1 Assessment of the BBB permeability of mefloquine, chloroquine, hydroxychloroquine and quinacrine based on predictive physicochemical properties $[78,79]$

\begin{tabular}{|c|c|c|c|c|c|c|}
\hline Antimalarial & $\begin{array}{l}\text { Molecular } \\
\text { weight }\end{array}$ & $\begin{array}{l}\text { PSA } \\
\left(\AA^{2}\right)^{\mathrm{a}}\end{array}$ & $\begin{array}{l}\log _{b} \\
\mathrm{D}_{7.4}\end{array}$ & $\begin{array}{l}\text { Number of } \mathrm{N} \text { and } \\
\mathrm{O} \text { atoms }\end{array}$ & $\operatorname{cLog} \mathrm{P}^{\mathrm{a}}$ & $\begin{array}{l}\text { clogP minus } \\
(\mathrm{N}+\mathrm{O})>0\end{array}$ \\
\hline Mefloquine & 377 & 46.7 & 0.5 & 3 & 4.0 & Yes \\
\hline Chloroquine $^{\mathrm{c}}$ & 319 & 27.6 & 1.6 & 3 & 5.1 & Yes \\
\hline Hydroxychloroquine ${ }^{c}$ & 335 & 47.9 & 2.0 & 4 & 4.1 & Yes \\
\hline Quinacrine & 399 & 36.9 & 2.3 & 4 & 6.2 & Yes \\
\hline
\end{tabular}

${ }^{a}$ Determined from ChemDraw Professional, Ver 15

${ }^{\mathrm{b}}$ Determined from ACD /Labs Version 12

${ }^{\mathrm{c}} \mathrm{pKa}$ values of chloroquine are 10.5 and 6.3. pKa values of hydroxychloroquine are 8.9 and 6.3. Determined from $\mathrm{ACD} /$ Labs Version 12 


\section{Effect of Antimalarials on Iron Metabolism}

Interference with iron accumulation has been postulated as one of the mechanisms by which chloroquine and hydroxychloroquine are beneficial against COVID-19 [62]. This could occur via an inhibitory effect of antimalarials on iron uptake into tissues (Fig. 4). An increase in brain iron level is found by nuclear microscopy of the rat hippocampus undergoing neuroinflammation after excitotoxic injury induced by kainate [88]. The increased iron in the brain is accompanied by increased expression of both a ferrireductase DCYTB1 [89] and DMT1 [89, 90]. Intraperitoneal injections of quinacrine resulted in reduced DMT1 expression and decreased numbers of ferric or ferrous iron-containing glial cells in the degenerating hippocampus after kainate lesions [90].

Basic drugs such as antimalarials are also able to affect iron uptake by inhibiting iron release from its transport protein, transferrin [91]. Moreover, DMT1 is a $\mathrm{H}^{+} / \mathrm{Fe}^{2+}$ symporter that needs a proton electrochemical potential gradient to drive the transport of iron from endosomes into the cytoplasm [92], and antimalarials could alter the $\mathrm{pH}$ environment that is necessary for DMT1 transporter activity in endosomes.

\section{Effect of Antimalarials on Viral Replication}

It has been shown in cell culture that antimalarials can affect coronavirus replication (reviewed in [93]). For example, chloroquine was found to have significant effects on viral cell entry and replication in vitro [94]. The exact mechanism is unknown, although one possibility is that it may be related to inhibition of $\mathrm{CPLA}_{2}$, which as mentioned, was found to be essential for an early step in coronavirus replication [60].

\section{Summary and Perspectives for Future Development}

COVID-19 is a pro-inflammatory-driven condition with loss of smell and taste, suggesting that it may affect the olfactory and gustatory systems and the brain. These effects may persist even after the virus has been cleared from the body [43]. Antimalarials could have a beneficial effect on COVID-19 through (1) $\mathrm{PLA}_{2}$ inhibition, (2) $\mathrm{pH}$ change in lysosomes, (3) modulation of iron metabolism [62] and (4) possible direct antiviral activity. At the same time, antimalarials have the ability to cross the BBB and thus be beneficial in alleviating COVID-19-induced changes in the CNS. Chloroquine and hydroxychloroquine were found to be effective in controlling neurosarcoidosis in human patients. The drugs may be beneficial in inexorable disease progression, in patients where corticosteroids are clearly contraindicated [95]. On the other hand, anti-inflammatory treatment with hydroxychloroquine for 18 months does not slow the rate of decline in early stage or mild Alzheimer's disease [96]. Further studies are needed to determine the structure-activity relationships of antimalarials to improve their efficacy for treatment of COVID-19. Such research may also be fruitful in combatting other forms of neuroinflammation associated with age-related neurological disorders.

Non-randomized or randomized controlled trials on patients with COVID-19 have identified benefits in clinical and virological outcomes with chloroquine or hydroxychloroquine treatment [97-99]. Other studies have reported no positive effects [100]. One meta-analysis of publicly available clinical reports suggests that chloroquine derivatives are effective in reducing mortality by a factor of 3 in patients infected with COVID-19 [101]. Few studies, however, have looked at CNS effects. At the time of writing of this paper, there are 35 ongoing trials investigating the use of the antimalarial drugs such as chloroquine and hydroxychloroquine against COVID-19, with another 34 more registered [102]. It is important to take note of what these ongoing clinical trials can eventually tell us about the use of antimalarials and other anti-inflammatory agents [99], for the treatment not only of COVID-19 but also of neuroinflammation and neurological/neurovascular disorders such as stroke and vascular dementia.

Acknowledgements We thank Dr. Shutish Patel, MD, Neurology Service, Middlesex Health, Middletown, Connecticut, USA, for valuable discussion and suggestions on the manuscript.

Funding This work was supported by a grant from the Ministry of Education, Singapore.

\section{Compliance with Ethical Standards}

Conflict of Interest The authors declare that they have no conflict of interest.

Open Access This article is licensed under a Creative Commons Attribution 4.0 International License, which permits use, sharing, adaptation, distribution and reproduction in any medium or format, as long as you give appropriate credit to the original author(s) and the source, provide a link to the Creative Commons licence, and indicate if changes were made. The images or other third party material in this article are included in the article's Creative Commons licence, unless indicated otherwise in a credit line to the material. If material is not included in the article's Creative Commons licence and your intended use is not permitted by statutory regulation or exceeds the permitted use, you will need to obtain permission directly from the copyright holder. To view a copy of this licence, visit http://creativecommons.org/licenses/by/4.0/.

\section{References}

1. Beauverd Y, Adam Y, Assouline B, Samii K (2020) COVID-19 infection and treatment with hydroxychloroquine cause severe 
haemolysis crisis in a patient with glucose-6-phosphate dehydrogenase deficiency. Eur J Haematol. https://doi.org/10.1111/ejh. 13432

2. Zheng HY, Zhang M, Yang CX, Zhang N, Wang XC, Yang XP, Dong XQ, Zheng YT (2020) Elevated exhaustion levels and reduced functional diversity of $\mathrm{T}$ cells in peripheral blood may predict severe progression in COVID-19 patients. Cell Mol Immunol 17(5):541-543. https://doi.org/10.1038/s41423-020-0401-3

3. Zhou Z, Ren L, Zhang L, Zhong J, Xiao Y, Jia Z, Guo L, Yang J et al (2020) Heightened innate immune responses in the respiratory tract of COVID-19 patients. Cell Host Microbe 27(6):883890 e882. https://doi.org/10.1016/j.chom.2020.04.017

4. Huang C, Wang Y, Li X, Ren L, Zhao J, Hu Y, Zhang L, Fan G et al (2020) Clinical features of patients infected with 2019 novel coronavirus in Wuhan, China. Lancet (London, England) 395(10223):497-506. https://doi.org/10.1016/S0140-6736(20) 30183-5

5. Liao M, Liu Y, Yuan J, Wen Y, Xu G, Zhao J, Cheng L, Li J et al (2020) Single-cell landscape of bronchoalveolar immune cells in patients with COVID-19. Nat Med 26(6):842-844. https://doi.org/ 10.1038/s41591-020-0901-9

6. Varga Z, Flammer AJ, Steiger P, Haberecker M, Andermatt R, Zinkernagel AS, Mehra MR, Schuepbach RA et al (2020) Endothelial cell infection and endotheliitis in COVID-19. Lancet (London, England) 395(10234):1417-1418. https://doi.org/10. 1016/S0140-6736(20)30937-5

7. Bikdeli B, Madhavan MV, Jimenez D, Chuich T, Dreyfus I, Driggin E, Nigoghossian C, Ageno W et al (2020) COVID-19 and thrombotic or thromboembolic disease: implications for prevention, antithrombotic therapy, and follow-up: JACC state-ofthe-art review. Journal of the American College of Cardiology 75(23):2950-2973. https://doi.org/10.1016/j.jacc.2020.04.031

8. Aboughdir M, Kirwin T, Abdul Khader A, Wang B (2020) Prognostic value of cardiovascular biomarkers in COVID-19: a review. Viruses 12(5). https://doi.org/10.3390/v12050527

9. Lee CY, Seet RC, Huang SH, Long LH, Halliwell B (2009) Different patterns of oxidized lipid products in plasma and urine of dengue fever, stroke, and Parkinson's disease patients: cautions in the use of biomarkers of oxidative stress. Antioxid Redox Signal 11(3):407-420. https://doi.org/10.1089/ARS.2008.2179

10. Larrayoz IM, Huang JD, Lee JW, Pascual I, Rodriguez IR (2010) 7-ketocholesterol-induced inflammation: involvement of multiple kinase signaling pathways via NFkappaB but independently of reactive oxygen species formation. Invest Ophthalmol Vis Sci 51(10):4942-4955. https://doi.org/10.1167/iovs.09-4854

11. Yang C, Xie L, Gu Q, Qiu Q, Wu X, Yin L (2019) 7 Ketocholesterol disturbs RPE cells phagocytosis of the outer segment of photoreceptor and induces inflammation through ERK signaling pathway. Exp Eye Res 189:107849. https://doi.org/10. 1016/j.exer.2019.107849

12. Koka S, Xia M, Chen Y, Bhat OM, Yuan X, Boini KM, Li PL (2017) Endothelial NLRP3 inflammasome activation and arterial neointima formation associated with acid sphingomyelinase during hypercholesterolemia. Redox Biol 13:336-344. https://doi. org/10.1016/j.redox.2017.06.004

13. Song J, Wang D, Chen H, Huang X, Zhong Y, Jiang N, Chen C, Xia M (2017) Association of plasma 7-ketocholesterol with cardiovascular outcomes and total mortality in patients with coronary artery disease. Circ Res 120(10):1622-1631. https://doi.org/10. 1161/CIRCRESAHA.117.311049

14. Wang M, Long W, Li D, Wang D, Zhong Y, Mu D, Song J, Xia M (2017) Plasma 7-ketocholesterol levels and the risk of incident cardiovascular events. Heart 103(22):1788-1794. https://doi.org/ 10.1136/heartjnl-2016-310914

15. Murakami H, Tamasawa N, Matsui J, Yasujima M, Suda T (2000) Plasma oxysterols and tocopherol in patients with diabetes mellitus and hyperlipidemia. Lipids 35(3):333-338. https://doi. org/10.1007/s11745-000-0530-1

16. Ong WY, Farooqui AA (2005) Iron, neuroinflammation, and Alzheimer's disease. J Alzheimers Dis 8(2):183-200; discussion 209-115. https://doi.org/10.3233/jad-2005-8211

17. Colafrancesco S, Alessandri C, Conti F, Priori R (2020) COVID19 gone bad: a new character in the spectrum of the hyperferritinemic syndrome? Autoimmun Rev 19(7):102573. https://doi.org/10.1016/j.autrev.2020.102573

18. Halliwell B, Gutteridge JMC (2015) Free radicals in biology and medicine Edn 5. Oxford University Press

19. Burdo JR, Menzies SL, Simpson IA, Garrick LM, Garrick MD, Dolan KG, Haile DJ, Beard JL et al (2001) Distribution of divalent metal transporter 1 and metal transport protein 1 in the normal and Belgrade rat. J Neurosci Res 66(6):1198-1207. https://doi.org/10. 1002/jnr. 1256

20. Lee PL, Gelbart T, West C, Halloran C, Beutler E (1998) The human Nramp2 gene: characterization of the gene structure, alternative splicing, promoter region and polymorphisms. Blood Cells Mol Dis 24(2):199-215. https://doi.org/10.1006/bcmd.1998.0186

21. Kishi F, Tabuchi M (1998) Human natural resistance-associated macrophage protein 2: gene cloning and protein identification. Biochem Biophys Res Commun 251(3):775-783. https://doi.org/ 10.1006/bbrc.1998.9415

22. Zhang X, Green MV, Thayer SA (2019) HIV gp120-induced neuroinflammation potentiates NMDA receptors to overcome basal suppression of inhibitory synapses by p38 MAPK. J Neurochem 148(4):499-515. https://doi.org/10.1111/jnc. 14640

23. Zubair AS, McAlpine LS, Gardin T, Farhadian S, Kuruvilla DE, Spudich S (2020) Neuropathogenesis and neurologic manifestations of the coronaviruses in the age of coronavirus disease 2019: a review. JAMA Neurol 77:1018. https://doi.org/10.1001/ jamaneurol.2020.2065

24. Fotuhi M, Mian A, Meysami S, Raji CA (2020) Neurobiology of COVID-19. J Alzheimers Dis 76(1):3-19. https://doi.org/10.3233/ jad-200581

25. Cataldi M, Pignataro G, Taglialatela M (2020) Neurobiology of coronaviruses: potential relevance for COVID-19. Neurobiol Dis 143:105007. https://doi.org/10.1016/j.nbd.2020.105007

26. Gane SB, Kelly C, Hopkins C (2020) Isolated sudden onset anosmia in COVID-19 infection. A novel syndrome? Rhinology 58(3): 299-301. https://doi.org/10.4193/Rhin20.114

27. Cooper KW, Brann DH, Farruggia MC, Bhutani S, Pellegrino R, Tsukahara T, Weinreb C, Joseph PV et al (2020) COVID-19 and the chemical senses: supporting players take center stage. Neuron 107(2):219-233. https://doi.org/10.1016/j.neuron.2020.06.032

28. Politi LS, Salsano E, Grimaldi M (2020) Magnetic resonance imaging alteration of the brain in a patient with coronavirus disease 2019 (COVID-19) and anosmia. JAMA Neurol. 77:1028. https:// doi.org/10.1001/jamaneurol.2020.2125

29. Laurendon T, Radulesco T, Mugnier J, Gerault M, Chagnaud C, El Ahmadi AA, Varoquaux A (2020) Bilateral transient olfactory bulb edema during COVID-19-related anosmia. Neurology 95(5): 224-225. https://doi.org/10.1212/WNL.0000000000009850

30. Balasubramanian SK, Poh KW, Ong CN, Kreyling WG, Ong WY, Yu LE (2013) The effect of primary particle size on biodistribution of inhaled gold nano-agglomerates. Biomaterials 34(22):5439-5452. https://doi.org/10.1016/j.biomaterials.2013. 03.080

31. Yu LE, Yung L, Ong CN, Tan YL, Balasubramanian SK, Hartono D, Wenk MR, Ong WY (2007) Translocation and effects of gold nanoparticles after inhalation exposure in rats. Nanotoxicology 1(3):235-242

32. Netland J, Meyerholz DK, Moore S, Cassell M, Perlman S (2008) Severe acute respiratory syndrome coronavirus infection causes neuronal death in the absence of encephalitis in mice transgenic 
for human ACE2. J Virol 82(15):7264-7275. https://doi.org/10. 1128/JVI.00737-08

33. Butowt R, Bilinska K (2020) SARS-CoV-2: olfaction, brain infection, and the urgent need for clinical samples allowing earlier virus detection. ACS Chem Neurosci 11(9):1200-1203. https:// doi.org/10.1021/acschemneuro.0c00172

34. Harberts E, Yao K, Wohler JE, Maric D, Ohayon J, Henkin R, Jacobson S (2011) Human herpesvirus-6 entry into the central nervous system through the olfactory pathway. Proc Natl Acad Sci U S A 108(33):13734-13739. https://doi.org/10.1073/pnas. 1105143108

35. De Felice FG, Tovar-Moll F, Moll J, Munoz DP, Ferreira ST (2020) Severe acute respiratory syndrome coronavirus 2 (SARSCoV-2) and the central nervous system. Trends Neurosci 43(6): 355-357. https://doi.org/10.1016/j.tins.2020.04.004

36. Sardu C, Gambardella J, Morelli MB, Wang X, Marfella R, Santulli G (2020) Hypertension, thrombosis, kidney failure, and diabetes: is COVID-19 an endothelial disease? A comprehensive evaluation of clinical and basic evidence. J Clin Med 9(5). https:// doi.org/10.3390/jcm9051417

37. von Weyhern CH, Kaufmann I, Neff F, Kremer M (2020) Early evidence of pronounced brain involvement in fatal COVID-19 outcomes. Lancet (London, England) 395(10241):e109. https:// doi.org/10.1016/S0140-6736(20)31282-4

38. Li YC, Bai WZ, Hashikawa T (2020) The neuroinvasive potential of SARS-CoV2 may play a role in the respiratory failure of COVID-19 patients. J Med Virol 92(6):552-555. https://doi.org/ 10.1002/jmv.25728

39. Mao L, Jin H, Wang M, Hu Y, Chen S, He Q, Chang J, Hong C et al (2020) Neurologic manifestations of hospitalized patients with coronavirus disease 2019 in Wuhan, China. JAMA Neurol 77(6):1-9. https://doi.org/10.1001/jamaneurol.2020.1127

40. Vespignani H, Colas D, Lavin BS, Soufflet C, Maillard L, Pourcher V, Paccoud O, Medjebar S et al (2020) Report on electroencephalographic findings in critically ill patients with COVID-19. Ann Neurol 88:626-630. https://doi.org/10.1002/ ana. 25814

41. Cabirac GF, Soike KF, Zhang JY, Hoel K, Butunoi C, Cai GY, Johnson S, Murray RS (1994) Entry of coronavirus into primate CNS following peripheral infection. Microb Pathog 16(5):349 357. https://doi.org/10.1006/mpat.1994.1035

42. Gu J, Gong E, Zhang B, Zheng J, Gao Z, Zhong Y, Zou W, Zhan J et al (2005) Multiple organ infection and the pathogenesis of SARS. J Exp Med 202(3):415-424. https://doi.org/10.1084/jem. 20050828

43. Zhou L, Zhang M, Wang J, Gao J (2020) Sars-Cov-2: underestimated damage to nervous system. Travel Medicine and Infectious Disease:101642. doi:https://doi.org/10.1016/j.tmaid. 2020.101642

44. De Santis G (2020) SARS-CoV-2: a new virus but a familiar inflammation brain pattern. Brain Behav Immun 87:95-96. https://doi.org/10.1016/j.bbi.2020.04.066

45. Poyiadji N, Shahin G, Noujaim D, Stone M, Patel S, Griffith B (2020) COVID-19-associated acute hemorrhagic necrotizing encephalopathy: imaging features. Radiology 296(2):E119-E120. https://doi.org/10.1148/radiol.2020201187

46. Agarwal S, Jain R, Dogra S, Krieger P, Lewis A, Nguyen V, Melmed K, Galetta S (2020) Cerebral microbleeds and leukoencephalopathy in critically ill patients with COVID-19. Stroke:STROKEAHA120030940. doi:https://doi.org/10.1161/ STROKEAHA.120.030940

47. Paniz-Mondolfi A, Bryce C, Grimes Z, Gordon RE, Reidy J, Lednicky J, Sordillo EM, Fowkes M (2020) Central nervous system involvement by severe acute respiratory syndrome coronavirus-2 (SARS-CoV-2). J Med Virol 92(7):699-702. https://oi.org/10.1002/jmv.25915
48. Divani AA, Andalib S, Di Napoli M, Lattanzi S, Hussain MS, Biller J, McCullough LD, Azarpazhooh MR et al (2020) Coronavirus disease 2019 and stroke: clinical manifestations and pathophysiological insights. Journal of stroke and cerebrovascular diseases : the official journal of National Stroke Association 29(8): 104941. https://doi.org/10.1016/j.jstrokecerebrovasdis.2020. 104941

49. Feng W, Wang Y, Liu ZQ, Zhang X, Han R, Miao YZ, Qin ZH (2017) Microglia activation contributes to quinolinic acid-induced neuronal excitotoxicity through TNF-alpha. Apoptosis : an international journal on programmed cell death 22(5):696-709. https:// doi.org/10.1007/s10495-017-1363-5

50. Wrapp D, Wang N, Corbett KS, Goldsmith JA, Hsieh CL, Abiona O, Graham BS, McLellan JS (2020) Cryo-EM structure of the 2019-nCoV spike in the prefusion conformation. Science (New York, NY) 367(6483):1260-1263. https://doi.org/10.1126/ science.abb2507

51. Palasca O, Santos A, Stolte C, Gorodkin J, Jensen LJ (2018) TISSUES 2.0: an integrative web resource on mammalian tissue expression. Database : The journal of biological databases and curation 2018. doi:https://doi.org/10.1093/database/bay028

52. Ong WY, Farooqui T, Kokotos G, Farooqui AA (2015) Synthetic and natural inhibitors of phospholipases A2: their importance for understanding and treatment of neurological disorders. ACS Chem Neurosci 6(6):814-831. https://doi.org/10.1021/ acschemneuro.5b00073

53. Farooqui AA, Ong WY, Horrocks LA (2006) Inhibitors of brain phospholipase A2 activity: their neuropharmacological effects and therapeutic importance for the treatment of neurologic disorders. Pharmacol Rev 58(3):591-620. https://doi.org/10.1124/pr.58.3.7

54. Chuang DY, Simonyi A, Kotzbauer PT, Gu Z, Sun GY (2015) Cytosolic phospholipase A2 plays a crucial role in ROS/NO signaling during microglial activation through the lipoxygenase pathway. J Neuroinflammation 12:199. https://doi.org/10.1186/ s12974-015-0419-0

55. Luo SF, Lin CC, Chen HC, Lin WN, Lee IT, Lee CW, Hsiao LD, Yang CM (2008) Involvement of MAPKs, NF-kappaB and p300 co-activator in IL-1beta-induced cytosolic phospholipase A2 expression in canine tracheal smooth muscle cells. Toxicol Appl Pharmacol 232(3):396-407. https://doi.org/10.1016/j.taap.2008. 07.019

56. Lee IT, Lin CC, Cheng SE, Hsiao LD, Hsiao YC, Yang CM (2013) TNF-alpha induces cytosolic phospholipase A2 expression in human lung epithelial cells via JNK1/2- and p38 MAPKdependent AP-1 activation. PLoS One 8(9):e72783. https://doi. org/10.1371/journal.pone.0072783

57. Rey A, M'Rini C, Sozzani P, Lamboeuf Y, Beraud M, Caput D, Ferrara P, Pipy B (1998) IL-13 increases the cPLA2 gene and protein expression and the mobilization of arachidonic acid during an inflammatory process in mouse peritoneal macrophages. Biochim Biophys Acta 1393(2-3):244-252. https://doi.org/10. 1016/s0005-2760(98)00080-0

58. He X, Jittiwat J, Kim JH, Jenner AM, Farooqui AA, Patel SC, Ong WY (2009) Apolipoprotein D modulates F2-isoprostane and 7 ketocholesterol formation and has a neuroprotective effect on organotypic hippocampal cultures after kainate-induced excitotoxic injury. Neurosci Lett 455(3):183-186. https://doi.org/ 10.1016/j.neulet.2009.03.038

59. Do Carmo S, Jacomy H, Talbot PJ, Rassart E (2008) Neuroprotective effect of apolipoprotein D against human coronavirus OC43-induced encephalitis in mice. J Neurosci 28(41): 10330-10338. https://doi.org/10.1523/JNEUROSCI.2644-08. 2008

60. Muller C, Hardt M, Schwudke D, Neuman BW, Pleschka S, Ziebuhr J (2018) Inhibition of cytosolic phospholipase A2alpha impairs an early step of coronavirus replication in cell culture. J 
Virol 92(4):JVI.01463-JVI.01417. https://doi.org/10.1128/JVI. 01463-17

61. Vijay R, Hua X, Meyerholz DK, Miki Y, Yamamoto K, Gelb M, Murakami M, Perlman S (2015) Critical role of phospholipase A2 group IID in age-related susceptibility to severe acute respiratory syndrome-CoV infection. J Exp Med 212(11):1851-1868. https:// doi.org/10.1084/jem.20150632

62. Quiros Roldan E, Biasiotto G, Magro P, Zanella I (2020) The possible mechanisms of action of 4-aminoquinolines (chloroquine/hydroxychloroquine) against Sars-Cov-2 infection (COVID-19): a role for iron homeostasis? Pharmacol Res 158: 104904. https://doi.org/10.1016/j.phrs.2020.104904

63. Homewood CA, Warhurst DC, Peters W, Baggaley VC (1972) Lysosomes, $\mathrm{pH}$ and the anti-malarial action of chloroquine. Nature 235(5332):50-52. https://doi.org/10.1038/ 235050a0

64. Zidovetzki R, Sherman IW, O'Brien L (1993) Inhibition of Plasmodium falciparum phospholipase A2 by chloroquine, quinine, and arteether. J Parasitol 79(4):565-570

65. Hostetler KY, Jellison EJ (1989) Role of phospholipases in myocardial ischemia: effect of cardioprotective agents on the phospholipases A of heart cytosol and sarcoplasmic reticulum in vitro. Mol Cell Biochem 88(1-2):77-82. https://doi.org/10.1007/ BF00223427

66. Bondeson J, Sundler R (1998) Antimalarial drugs inhibit phospholipase A2 activation and induction of interleukin 1 beta and tumor necrosis factor alpha in macrophages: implications for their mode of action in rheumatoid arthritis. Gen Pharmacol 30(3):357-366. https://doi.org/10.1016/ s0306-3623(97)00269-3

67. Ong WY, Lu XR, Ong BK, Horrocks LA, Farooqui AA, Lim SK (2003) Quinacrine abolishes increases in cytoplasmic phospholipase A2 mRNA levels in the rat hippocampus after kainateinduced neuronal injury. Exp Brain Res 148(4):521-524. https:// doi.org/10.1007/s00221-002-1315-2

68. Lu XR, Ong WY, Halliwell B, Horrocks LA, Farooqui AA (2001) Differential effects of calcium-dependent and calciumindependent phospholipase $\mathrm{A}(2)$ inhibitors on kainate-induced neuronal injury in rat hippocampal slices. Free Radic Biol Med 30(11):1263-1273. https://doi.org/10.1016/s0891-5849(01) 00528-7

69. Ong WY, Lu XR, Horrocks LA, Farooqui AA, Garey LJ (2003) Induction of astrocytic cytoplasmic phospholipase A2 and neuronal death after intracerebroventricular carrageenan injection, and neuroprotective effects of quinacrine. Exp Neurol 183(2):449 457. https://doi.org/10.1016/s0014-4886(03)00174-2

70. Stuhlmeier KM (2001) Effects of quinacrine on endothelial cell morphology and transcription factor-DNA interactions. Biochim Biophys Acta 1524(1):57-65. https://doi.org/10.1016/s03044165(00)00140-9

71. Farooqui AA, Ong WY, Horrocks LA (2004) Neuroprotection abilities of cytosolic phospholipase A2 inhibitors in kainic acidinduced neurodegeneration. Current drug targets Cardiovascular \& haematological disorders 4(1):85-96. https://doi.org/10.2174/ 1568006043481239

72. Han WK, Sapirstein A, Hung CC, Alessandrini A, Bonventre JV (2003) Cross-talk between cytosolic phospholipase A2 alpha (cPLA2 alpha) and secretory phospholipase A2 (sPLA2) in hydrogen peroxide-induced arachidonic acid release in murine mesangial cells: sPLA2 regulates cPLA2 alpha activity that is responsible for arachidonic acid release. J Biol Chem 278(26):24153-24163. https://doi.org/10.1074/jbc.M300424200

73. Bosetti F, Weerasinghe GR (2003) The expression of brain cyclooxygenase- 2 is down-regulated in the cytosolic phospholipase A2 knockout mouse. J Neurochem 87(6):14711477. https://doi.org/10.1046/j.1471-4159.2003.02118.x

74. Danta CC (2020) CNS penetration ability: a critical factor for drugs in the treatment of SARS-CoV-2 brain infection. ACS Chem Neurosci 11:2137-2144. https://doi.org/10.1021/ acschemneuro.0c00335

75. Jones R, Kunsman G, Levine B, Smith M, Stahl C (1994) Mefloquine distribution in postmortem cases. Forensic Sci Int 68(1):29-32. https://doi.org/10.1016/0379-0738(94)90376-x

76. Pham YT, Nosten F, Farinotti R, White NJ, Gimenez F (1999) Cerebral uptake of mefloquine enantiomers in fatal cerebral malaria. Int J Clin Pharmacol Ther 37(1):58-61

77. Li D, Harvel KE (2016) Drug-like properties: concepts, structure design and methods from ADME to toxicity optimization. Academic Press, Elsevier

78. Clark DE (2003) In silico prediction of blood-brain barrier permeation. Drug Discov Today 8(20):927-933. https://doi.org/10. 1016/s1359-6446(03)02827-7

79. Lobell M, Molnar L, Keseru GM (2003) Recent advances in the prediction of blood-brain partitioning from molecular structure. $\mathrm{J}$ Pharm Sci 92(2):360-370. https://doi.org/10.1002/jps.10282

80. Nguyen T, Sakasegawa Y, Doh-Ura K, Go ML (2011) Anti-prion activities and drug-like potential of functionalized quinacrine analogs with basic phenyl residues at the 9-amino position. Eur J Med Chem 46(7):2917-2929. https://doi.org/10.1016/j.ejmech. 2011.04.016

81. Baig AM, Khaleeq A, Ali U, Syeda H (2020) Evidence of the COVID-19 virus targeting the CNS: tissue distribution, hostvirus interaction, and proposed neurotropic mechanisms. ACS Chem Neurosci 11(7):995-998. https://doi.org/10.1021/ acschemneuro.0c00122

82. Lu XR, Ong WY, Halliwell B (2001) The phospholipase A2 inhibitor quinacrine prevents increased immunoreactivity to cytoplasmic phospholipase A2 (cPLA2) and hydroxynonenal (HNE) in neurons of the lateral septum following fimbria-fornix transection. Exp Brain Res 138(4):500-508. https://doi.org/10.1007/ s002210100737

83. Dubin NH, Blake DA, DiBlasi MC, Parmley TH, King TM (1982) Pharmacokinetic studies on quinacrine following intrauterine administration to cynomolgus monkeys. Fertil Steril 38(6):735-740. https://doi.org/10.1016/s0015-0282(16)46703-8

84. Lee KCH, Sewa DW, Phua GC (2020) Potential role of statins in COVID-19. International journal of infectious diseases: IJID : official publication of the International Society for Infectious Diseases 96:615-617. https://doi.org/10.1016/j.ijid.2020.05.115

85. Rodrigues-Diez RR, Tejera-Munoz A, Marquez-Exposito L, Rayego-Mateos S, Santos Sanchez L, Marchant V, Tejedor Santamaria L, Ramos AM et al (2020) Statins: could an old friend help in the fight against COVID-19? Br J Pharmacol. https://doi. org/10.1111/bph. 15166

86. Zhang XJ, Qin JJ, Cheng X, Shen L, Zhao YC, Yuan Y, Lei F, Chen MM et al (2020) In-hospital use of statins is associated with a reduced risk of mortality among individuals with COVID-19. Cell Metab 32(2):176-187 e174. https://doi.org/10.1016/j.cmet. 2020.06.015

87. Nguyen TH, Lee CY, Teruya K, Ong WY, Doh-ura K, Go ML (2008) Antiprion activity of functionalized 9-aminoacridines related to quinacrine. Bioorg Med Chem 16(14):6737-6746. https:// doi.org/10.1016/j.bmc.2008.05.060

88. Ong WY, Ren MQ, Makjanic J, Lim TM, Watt F (1999) A nuclear microscopic study of elemental changes in the rat hippocampus after kainate-induced neuronal injury. J Neurochem 72(4):1574 1579. https://doi.org/10.1046/j.1471-4159.1999.721574.x

89. Loke SY, Siddiqi NJ, Alhomida AS, Kim HC, Ong WY (2013) Expression and localization of duodenal cytochrome $b$ in the rat 
hippocampus after kainate-induced excitotoxicity. Neuroscience 245:179-190. https://doi.org/10.1016/j.neuroscience.2013.04.008

90. Wang XS, Ong WY, Connor JR (2003) Quinacrine attenuates increases in divalent metal transporter-1 and iron levels in the rat hippocampus, after kainate-induced neuronal injury. Neuroscience 120(1):21-29. https://doi.org/10.1016/s03064522(03)00293-8

91. Paterson S, Armstrong NJ, Iacopetta BJ, McArdle HJ, Morgan EH (1984) Intravesicular $\mathrm{pH}$ and iron uptake by immature erythroid cells. J Cell Physiol 120(2):225-232. https://doi.org/10.1002/jcp. 1041200217

92. Shawki A, Knight PB, Maliken BD, Niespodzany EJ, Mackenzie B (2012) H(+)-coupled divalent metal-ion transporter-1: functional properties, physiological roles and therapeutics. Curr Top Membr 70:169-214. https://doi.org/10.1016/B978-0-12-3943163.00005-3

93. Meo SA, Klonoff DC, Akram J (2020) Efficacy of chloroquine and hydroxychloroquine in the treatment of COVID-19. European review for medical and pharmacological sciences 24(8):45394547. https://doi.org/10.26355/eurrev_202004_21038

94. Wang M, Cao R, Zhang L, Yang X, Liu J, Xu M, Shi Z, Hu Z et al (2020) Remdesivir and chloroquine effectively inhibit the recently emerged novel coronavirus (2019-nCoV) in vitro. Cell Res 30(3): 269-271. https://doi.org/10.1038/s41422-020-0282-0

95. Sharma OP (1998) Effectiveness of chloroquine and hydroxychloroquine in treating selected patients with sarcoidosis with neurological involvement. Arch Neurol 55(9):1248-1254. https://doi.org/10.1001/archneur.55.9.1248

96. Van Gool WA, Weinstein HC, Scheltens P, Walstra GJ (2001) Effect of hydroxychloroquine on progression of dementia in early Alzheimer's disease: an 18-month randomised, double-blind, placebo-controlled study. Lancet (London, England) 358(9280): 455-460. https://doi.org/10.1016/s0140-6736(01)05623-9
97. Huang M, Tang T, Pang P, Li M, Ma R, Lu J, Shu J, You Y et al (2020) Treating COVID-19 with chloroquine. J Mol Cell Biol 12(4):322-325. https://doi.org/10.1093/jmcb/mjaa014

98. Gautret P, Lagier JC, Parola P, Hoang VT, Meddeb L, Mailhe M, Doudier B, Courjon J et al (2020) Hydroxychloroquine and azithromycin as a treatment of COVID-19: results of an openlabel non-randomized clinical trial. Int J Antimicrob Agents 56(1):105949. https://doi.org/10.1016/j.ijantimicag.2020.105949

99. Zhang W, Zhao Y, Zhang F, Wang Q, Li T, Liu Z, Wang J, Qin Y et al (2020) The use of anti-inflammatory drugs in the treatment of people with severe coronavirus disease 2019 (COVID-19): the perspectives of clinical immunologists from China. Clinical immunology (Orlando, Fla) 214:108393. https://doi.org/10.1016/j. clim.2020.108393

100. Tang W, Cao Z, Han M, Wang Z, Chen J, Sun W, Wu Y, Xiao W et al (2020) Hydroxychloroquine in patients with mainly mild to moderate coronavirus disease 2019: open label, randomised controlled trial. BMJ (Clinical research ed) 369:m1849. https://doi. org/10.1136/bmj.m1849

101. Million M, Gautret P, Colson P, Roussel Y, Dubourg G, Chabriere E, Honore S, Rolain J-M et al (2020) Clinical efficacy of chloroquine derivatives in COVID-19 infection: comparative metaanalysis between the Big data and the real world. New Microbes and New Infections:100709. https://doi.org/10.1016/j.nmni.2020. 100709

102. Lythgoe MP, Middleton P (2020) Ongoing clinical trials for the management of the COVID-19 pandemic. Trends Pharmacol Sci 41(6):363-382. https://doi.org/10.1016/j.tips.2020.03.006

Publisher's Note Springer Nature remains neutral with regard to jurisdictional claims in published maps and institutional affiliations. 